\title{
KAJIAN KUALITAS LINGKUNGAN KERJA DAN PENERAPAN STANDAR OPERASIONAL PROSEDUR BENGKEL SERVIS KENDARAAN TERHADAP KESEHATAN PEKERJA MEKANIK SEPEDA MOTOR DI KOTA DENPASAR
}

\author{
I M. Juli Arsana ${ }^{1 *}$, I W. Redi Aryanta ${ }^{2)}$ I. B. Sudana ${ }^{2)}$ \\ ${ }^{1)}$ Balai Hiperkes dan Keselamatan Kerja Propinsi Bali \\ 2)Program Studi Magister Ilmu Lingkungan Universitas Udayana \\ "Email : julihiperkes09@gmail.com / anak.kelating@gmail.com
}

\begin{abstract}
Increasing the number and motorcycle ownership provides increased workload and environmental load in the vehicle workshop. This research was conducted with the aim of analyzing the influence of the quality of the working environment and the application of standard operating procedures work vehicle servicing workshop on the health of workers mechanical workshop in Denpasar. Environmental variables measured in the form of $\mathrm{CO}$ (carbon monoxide), dust, lighting, noise and work climate as well as assessing the implementation of labor standard operating procedures vehicle repair workshop. Also assessed lung function, musculoskeletal complaints and fatigue were identified employee. Analysis of data using simple regression to the effect of each variable was continued regression to assess the influence of several variables on the health of the mechanical environment. Significance value used is á $=0.15(\mathrm{CI}=85 \%)$.

From 20 workshops and 101 workers were examined as a mechanic samples were obtained the following results: the working environment workshop dust parameter exceeds the quality standards. For the implementation of standard operating procedures parameters in a motorcycle shop can not all be met. Motorcycle mechanic workers were found to have complaints on lung function, musculoskeletal and experience fatigue. From the analysis it was found that all the variables on the quality of the environment and the implementation of standard work procedures workshop has a relationship to the health of workers motorcycle mechanic in Denpasar, but the only variable ambient $\mathrm{CO}(\mathrm{R}>0.697)$ and dust working environment $(\mathrm{R}=$ $0.612)$ were influential significantly $(\mathrm{R}>0.50)$.
\end{abstract}

Keywords : Work Environment; Motorcycle Workshop; Health; Mechanical Workers

\section{PENDAHULUAN}

Dunia transportasi di tanah air berkembang dengan sangat pesat dengan peningkatan jumlah kendaraan sebesar 12\% pada tahun 2012 (Korlantas Polri, 2012). Di Propinsi Bali peningkatan jumlah kendaraan khususnya roda dua sangat signifikan. Dinas Perhubungan Propinsi Bali (2011) melaporkan terjadi peningkatan jumlah kendaraan dari 698.558 unit di tahun 2000 menjadi 1.755 .753 unit di tahun 2010. Hal ini memicu peningkatan terhadap jumlah polutan, penggunaan energi dan juga penurunan kualitas lingkungan (Sayoga, 2001; Tugaswati, 2012). Peningkatan jumlah kendaraan roda dua memerlukan juga peningkatan kualitas layanan purna jual kendaraan khususnya bengkel sepeda motor untuk perawatan kendaraan. Aktivitas servis di ruang servis memberikan pengaruh terhadap kesehatan kerja para mekanik sebagai akibat peningkatan volume servis kendaraan (Daryanto, 2010; Mahardika, 2012). Oleh karena itu, diperlukan penerapan prosedur kerja yang baik serta kualitas lingkungan kerja yang baik agar mekanik senantiasa dapat bekerja dengan sehat dan aman (Suma'mur, 1980; Harrianto, 2010). Berdasarkan fenomena tersebut, penelitian ini dilakukan dengan tujuan menganalisis pengaruh kualitas lingkungan kerja dan penerapan prosedur operasi standar kerja bengkel servis kendaraan terhadap kesehatan pekerja mekanik bengkel di Kota Denpasar. Penelitian bertujuan untuk menganalisis pengaruh kualitas lingkungan kerja dan penerapan prosedur operasi standar kerja bengkel servis kendaraan terhadap kesehatan pekerja mekanik bengkel di Kota Denpasar.

\section{METODOLOGI}

Dilihat dari jenisnya, penelitian ini termasuk penelitian observational analitic. Dilihat dari waktu pelaksanaannya, termasuk ke dalam penelitian cross sectional yaitu penelitian yang dilakukan sesaat pada jangka waktu tertentu (Sugiyono, 2014). Penelitian dilakukan selama 5 bulan pada bulan Januari 2015 sampai dengan Mei 2015.

Pengukuran kualitas lingkungan kerja dilakukan di stasiun kerja para pekerja mekanik kendaraan. Pengukuran ini dilakukan di satu titik pada masing-masing ruang servis bengkel dengan 
mengukur gas $\mathrm{CO}$, debu, pengukuran bising kerja dan suhu ruangan. Nilai pengukuran akan dibandingkan dengan baku mutu yaitu Peraturan Gubernur Bali No. 8 Tahun 2007 Tentang Baku Mutu Lingkungan (Gubernur Bali, 2007), Kemenkes 1405/ Menkes/SK/XI/2002 Tentang Persyaratan Lingkungan Kerja Perkantoran dan Industri (Menteri Kesehatan RI, 2002), dan Permenakertrans RI No. Per.13/Men/X/2011 Tentang Nilai Ambang Batas Faktor Fisika dan Faktor Kimia di Tempat Kerja (Menteri Tenaga Kerja dan Transmigrasi RI, 2011).

Identifikasi keluhan kesehatan pekerja mekanik dilakukan dengan melakukan wawancara dengan menggunakan kuesioner Nordic Body Map untuk menilai keluhan muskuloskeletal (Kuorinka et al., 1987) serta kuesioner SSRT (Subjective Self Rating Test) untuk mengetahui keluhan kelelahan Pekerja mekanik bengkel dari IFRC (International Fatigue Research Centre) (Saito, 1999). Pelaksanaan standar operasional prosedur dievaluasi dengan menggunakan checklist yang berisikan prosedur standar dasar yang harus dilakukan oleh para mekanik dalam bekerja. Pengaruh masing-masing variabel dianalisis dengan menggunakan regresi sederhana untuk pengaruh masing-masing variabel dilanjutkan regresi berganda untuk menilai pengaruh beberapa variabel lingkungan terhadap kesehatan para mekanik. Nilai signifikansi yang dipakai yaitu á $=0,15(\mathrm{CI}=85 \%)$.

\section{HASIL DAN PEMBAHASAN}

\subsection{Karakteristik Pekerja Mekanik Bengkel Sepeda Motor di Kota Denpasar}

Dari 20 bengkel dan 101 orang mekanik yang diperiksa sebagai sampel didapatkan hasil bahwa sebanyak 20,8\% merupakan pekerja mekanik karyawan di bengkel kelas A, 49,5\% pekerja mekanik di bengkel kelas B, serta $29,7 \%$ pekerja mekanik di bengkel kelas C. Dari jumlah tersebut, pekerja mekanik bengkel secara keseluruhan berjenis kelamin pria didominasi oleh mekanik usia muda, di mana sebanyak $39,6 \%$ merupakan usia 20 - 25 tahun dan 17,8\% merupakan usia 26-30 tahun, dengan dominan masa kerja 1-2 tahun $(31,7 \%)$ dan 3-4 tahun (20,8\%).

Apabila ditinjau dari pendidikannya, para pekerja mekanik sepeda motor sebagian besar merupakan lulusan dengan pendidikan tingkat menengah yaitu setingkat SMU/SMK sebanyak $74,3 \%$ dan diploma otomotif $15,8 \%$. Para karyawan mekanik lulusan sarjana menempati posisi sebagai supervisor atau kepala tim atau kepala bengkel dengan jumlah 9,9\%. Berdasarkan atas kualifikasi pendidikan yang dimiliki oleh para karyawan mekanik sepeda motor tersebut, dapat dilihat bahwa pekerjaan di bidang otomotif memiliki standar yang ketat, di mana mengharuskan setiap orang memiliki kompetensi yang sesuai dengan pekerjaan yang akan digelutinya. Pekerjaan di bidang servis mesin dan kendaraan merupakan pekerjaan dengan komposisi skill yang dominan sehingga bagi pekerja yang tidak memiliki keahlian dan terlatih akan cukup kesulitan untuk melakukan pekerjaan tersebut.

Dilihat dari status gizinya sebagian besar (74,3\%) karyawan memiliki status gizi normal melalui cerminan nilai IMT (indeks massa tubuh). Sebanyak 8,9 \% mekanik mengalami status gizi kurang (kurus), serta ditemukan juga sebesar 16,8 $\%$ merupakan karyawan mekanik dengan status gizi lebih atau kegemukan. Selengkapnya tentang status gizi pekerja mekanik di Kota Denpasar ditampilkan dalam Gambar 1.

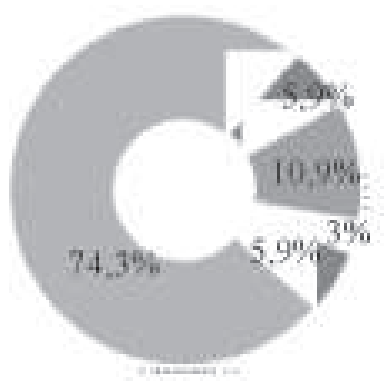

- Kuming Th. Berat

- KurangTk Ringan

- Nomal

- Lebih Tk Ringan

- Lebih Tk Berat

Gambar 1. Hasil Pengukuran Indeks Massa Tubuh (IMT) Karyawan Mekanik Sepeda Motor di Kota Denpasar Tahun 2015.

Pada penelitian ini juga didata tentang kebiasaan merokok pekerja mekanik di Kota Denpasar. Dari wawancara diketahui bahwa sebanyak $74,3 \%$ pekerja mekanik merupakan perokok aktif.

\subsection{Pengukuran Fungsi Paru Pekerja Mekanik Bengkel Sepeda Motor di Kota Denpasar}

Pada pengukuran fungsi paru pekerja mekanik, ditemukan 42,6\% dengan fungsi paru normal dan $36,6 \%$ ditemukan dengan restriksi paru serta $11,9 \%$ dengan obstruksi paru ringan. Combine defect pada fungsi paru ditemukan pada 7,9\% pekerja mekanik bengkel. Gambaran hasil selengkapnya tentang fungsi paru pekerja mekanik dapat dilihat pada Gambar 2. Pada pengukuran ini tidak ditemukan karyawan dengan kategori obstruksi paru sedang dan berat.

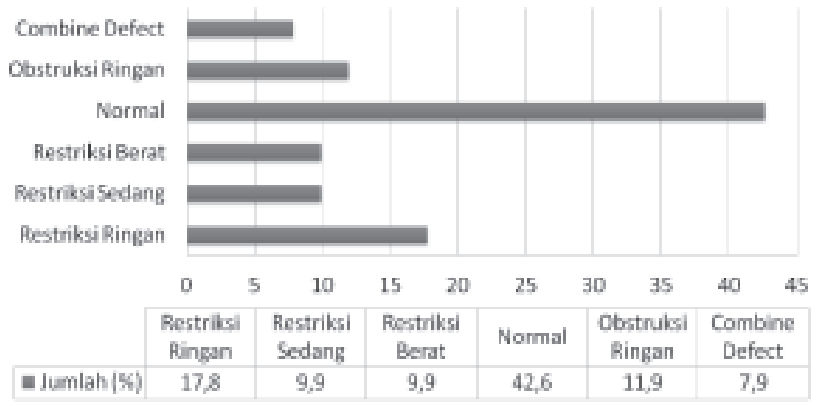

Gambar 2. Hasil Pengukuran Fungsi Paru Pekerja Mekanik Sepeda Motor Kota Denpasar Tahun 2015. 
Seseorang dikategorikan memiliki fungsi paru normal apabila nilai FVC $>80 \%$ dan FEV /FVC e" $75 \%$ (Mc Kay et al., dalam Budiono, 2007). Dari segi umur, ditemukan frekuensi distribusi kelainan paru banyak terdapat di usia 20-25 tahun, yaitu sebanyak 9,9\% dengan restriksi ringan, 5,0\% dengan restriksi sedang dan 5,9\% restriksi berat. Pada kelompok umur ini juga terlihat merupakan kelompok dengan obstruksi ringan terbanyak (4,0\%). Selengkapnya dapat dilihat pada Tabel 1.

Fungsi paru dilihat berdasarkan masa kerja pekerja mekanik (Tabel 2), ditemukan bahwa pekerja dengan masa kerja 1-2 tahun dan 3-4 tahun merupakan kelompok dengan hasil fungsi paru yang tidak normal dengan persentase terbesar. Kasus restriksi paru ditemukan paling banyak pada masa kerja 1-2 tahun dengan $12 \%$ dan 3-4 tahun dengan $11 \%$. Untuk kasus obstruksi ringan paling banyak pada masa kerja 3-4 tahun (4,0\%)

Tabel 1. Distribusi Frekuensi Fungsi Paru Berdasarkan Umur Mekanik Sepeda Motor di Kota Denpasar Tahun 2015.

\begin{tabular}{|c|c|c|c|c|c|c|c|c|}
\hline \multirow{2}{*}{\multicolumn{2}{|c|}{ FUNGSI PARU }} & \multicolumn{6}{|c|}{ UMUR (th) } & \multirow{2}{*}{ Total $(\%)$} \\
\hline & & $<20$ & $20-25$ & $26-30$ & $31-35$ & $36 \cdot 40$ & $>40$ & \\
\hline \multirow[t]{2}{*}{ Normal } & & $\begin{array}{c}6 \\
(5,9 \%)\end{array}$ & $\begin{array}{c}13 \\
(12,9 \%)\end{array}$ & $\begin{array}{c}9 \\
(8.9 \%)\end{array}$ & $\begin{array}{c}8 \\
(7.9 \%)\end{array}$ & $\begin{array}{c}7 \\
(6.9 \%)\end{array}$ & $\begin{array}{c}0 \\
(0,0 \%)\end{array}$ & $\begin{array}{c}43 \\
(42,6 \%)\end{array}$ \\
\hline & Ringan & $\begin{array}{c}1 \\
(1,0 \%)\end{array}$ & $\begin{array}{c}10 \\
(9,9 \%)\end{array}$ & $\begin{array}{c}2 \\
(2,0 \%)\end{array}$ & $\begin{array}{c}4 \\
(4.0 \%)\end{array}$ & $\begin{array}{c}0 \\
(0,0 \%)\end{array}$ & $\begin{array}{c}1 \\
(1,0 \%)\end{array}$ & $\begin{array}{c}18 \\
(17,8 \%)\end{array}$ \\
\hline \multirow[t]{2}{*}{ Restriksi } & Sedang & $\frac{1}{(10 \%)}$ & $\begin{array}{c}5 \\
(5,0 \%)\end{array}$ & $\begin{array}{c}3 \\
(3.0 \%)\end{array}$ & $\begin{array}{c}1 \\
(1,0 \%)\end{array}$ & $\begin{array}{c}0 \\
(0,0 \%)\end{array}$ & $\begin{array}{c}0 \\
(0,0 \%)\end{array}$ & $\begin{array}{c}10 \\
(9,95 \%)\end{array}$ \\
\hline & Berat & $\begin{array}{c}1 \\
(1,0 \%)\end{array}$ & $\begin{array}{c}6 \\
(5.9 \%)\end{array}$ & $\begin{array}{c}2 \\
(2,0 \%)\end{array}$ & $\begin{array}{c}0 \\
(0,0 \%)\end{array}$ & $\begin{array}{c}1 \\
(1,0 \%)\end{array}$ & $\begin{array}{c}0 \\
(0,0 \%)\end{array}$ & $\begin{array}{c}10 \\
(9,9 \%)\end{array}$ \\
\hline Obstruksi & Ringan & $\begin{array}{c}2 \\
(2,0 \%)\end{array}$ & $\begin{array}{c}4 \\
(4.0 \%)\end{array}$ & $\begin{array}{c}1 \\
(1,0 \%)\end{array}$ & $\begin{array}{c}2 \\
(2,0 \%)\end{array}$ & $\begin{array}{c}1 \\
(1,0 \%)\end{array}$ & $\begin{array}{c}2 \\
(2,0 \%)\end{array}$ & $\begin{array}{c}12 \\
(11,9 \%)\end{array}$ \\
\hline \multicolumn{2}{|c|}{ Combined defect } & $\begin{array}{c}3 \\
(3.0 \%)\end{array}$ & $\begin{array}{c}2 \\
(2,0 \%)\end{array}$ & $\begin{array}{c}1 \\
(1,0 \%)\end{array}$ & $\begin{array}{c}0 \\
(0,0 \%)\end{array}$ & $\begin{array}{c}1 \\
(1,0 \%)\end{array}$ & $\begin{array}{c}1 \\
(1,0 \%)\end{array}$ & $\begin{array}{c}8 \\
(7,9 \%) \\
\end{array}$ \\
\hline
\end{tabular}

Tabel 2. Distribusi Frekuensi Fungsi Paru Berdasarkan Masa Kerja Karyawan Mekanik Sepeda Motor di Kota Denpasar Tahun 2015.

\begin{tabular}{|c|c|c|c|c|c|c|c|c|}
\hline \multirow{2}{*}{\multicolumn{2}{|c|}{ FUNGSI PARU }} & \multicolumn{6}{|c|}{ MASA KERJA (th) } & \multirow{2}{*}{$\begin{array}{c}\text { Total } \\
(\%)\end{array}$} \\
\hline & & $1-2$ & $3-4$ & $5-6$ & $7-8$ & $9-10$ & $>10$ & \\
\hline \multirow[t]{2}{*}{ Nomal } & & $\begin{array}{c}13 \\
(12,9 \%)\end{array}$ & $\begin{array}{c}6 \\
(5,9 \%)\end{array}$ & $\begin{array}{c}2 \\
(2,00 \%)\end{array}$ & $\begin{array}{c}5 \\
6,0 \%\end{array}$ & $\begin{array}{c}7 \\
(6.9 \%)\end{array}$ & $\begin{array}{c}10 \\
(9,9 \%)\end{array}$ & $\begin{array}{c}43 \\
(42,6 \%)\end{array}$ \\
\hline & & $\begin{array}{l}5 \\
(50 \%)\end{array}$ & $\begin{array}{c}5 \\
(5,0 \%)\end{array}$ & $\begin{array}{c}2 \\
(2,0 \%)\end{array}$ & $\begin{array}{c}1 \\
(1,0 \%)\end{array}$ & $\begin{array}{c}1 \\
(1,0 \%)\end{array}$ & $\begin{array}{c}4 \\
(4,0 \%)\end{array}$ & $\begin{array}{c}18 \\
(17,8 \%)\end{array}$ \\
\hline Restriksi & Sedang & $\begin{array}{c}3 \\
(3,0 \%) \\
4 \\
(4,0 \%)\end{array}$ & $\begin{array}{c}3 \\
(3,0 \%) \\
3 \\
(3,0 \%)\end{array}$ & $\begin{array}{c}2 \\
(2,0 \%) \\
0 \\
\left(0,0^{0}\right)\end{array}$ & $\begin{array}{c}1 \\
(1,0 \%) \\
2 \\
(2,0 \%)\end{array}$ & $\begin{array}{c}1 \\
(1,0 \%) \\
0 \\
(0,0 \%)\end{array}$ & $\begin{array}{c}0 \\
(0,0 \%) \\
1 \\
(1,0 \%)\end{array}$ & $\begin{array}{c}10 \\
(9,9 \%) \\
10 \\
(9,9 \%)\end{array}$ \\
\hline Obstruksi & Ringan & $\begin{array}{c}3 \\
(3,0 \%)\end{array}$ & $\begin{array}{c}3 \\
(3.0 \%)\end{array}$ & $\begin{array}{c}1 \\
(1,0 \%)\end{array}$ & $\begin{array}{c}0 \\
(0,0 \%)\end{array}$ & $\begin{array}{c}1 \\
(1,0 \%)\end{array}$ & $\begin{array}{c}4 \\
(4,0 \%)\end{array}$ & $\begin{array}{c}12 \\
(11,9 \%)\end{array}$ \\
\hline Combined & & $\begin{array}{c}4 \\
(4,00 \%)\end{array}$ & $\begin{array}{c}1 \\
(1,0 \%)\end{array}$ & $\begin{array}{c}0 \\
(0,0 \%\end{array}$ & $\begin{array}{c}0 \\
(0,0 \%)\end{array}$ & $\begin{array}{c}1 \\
(1,0 \%)\end{array}$ & $\begin{array}{c}2 \\
(2,0 \%)\end{array}$ & $\begin{array}{c}8 \\
(79 \%) \\
9\end{array}$ \\
\hline
\end{tabular}

Fungsi paru pekerja mekanik juga dilihat berdasarkan atas kebiasaan merokok para pekerja. Berdasarkan hal tersebut diketahui bahwa gangguan fungsi paru sejalan dengan kebiasaan merokok, di mana jumlah pekerja dengan gangguan fungsi paru ditemukan paling besar pada populasi merokok seperti pada Tabel 3. Kasus restriksi paru pada perokok ditemukan sebanyak $36,6 \%$, serta kasus obstruksi ringan sebanyak 8,9\%. Sisanya sebesar 7,9\% merupakan pekerja dengan combine defect paru. Pada pekerja yang tidak merokok ditemukan kasus obstruksi sebanyak 3,0\% serta restriksi ringan sebanyak 1,0\%. Woodhouse et al. (2003) dari Sheffield University, melakukan penelitian penurunan ventilasi paru dengan menggunakan MRI (Magnetic Resonance Imaging) dengan metode SSFSE (Single Shot Fast Spin Echo) terhadap orang merokok dan bukan merokok, menemukan bahwa terjadi penurunan rata-rata pada volume paru (mean ventilated volume reduction) sebesar $24,8 \%$ pada perokok aktif dibandingkan dengan yang bukan perokok. Nilai penurunan ini ditemukan meningkat menjadi $34,4 \%$ pada perokok dengan penyakit paru obstruktif kronis.

Tabel 3. Distribusi Frekuensi Fungsi Paru Berdasarkan Kebiasaan Merokok Mekanik Sepeda Motor di Kota Denpasar Tahun 2015.

\begin{tabular}{|c|c|c|c|c|}
\hline \multirow{2}{*}{\multicolumn{2}{|c|}{ FUNGSI PARI }} & \multicolumn{2}{|c|}{ MEROKOK } & \multirow{2}{*}{ Total (\%) } \\
\hline & & TIDAK & $\mathrm{YA}$ & \\
\hline \multicolumn{2}{|l|}{ Normal } & $\begin{array}{c}22 \\
(21.8 \%)\end{array}$ & $\begin{array}{c}21 \\
(20.8 \%)\end{array}$ & $\begin{array}{c}43 \\
(42.6 \%)\end{array}$ \\
\hline \multirow{3}{*}{ Restriksi } & $R$ ing a $n$ & $\begin{array}{c}1 \\
(1,0 \%)\end{array}$ & $\begin{array}{c}17 \\
(16,8 \%)\end{array}$ & $\begin{array}{c}18 \\
(17,8 \%)\end{array}$ \\
\hline & Sedang & $\begin{array}{c}0,0 \\
(0,0 \%)\end{array}$ & $\begin{array}{c}10 \\
(9,9 \%)\end{array}$ & $\begin{array}{c}10 \\
(9,9 \%)\end{array}$ \\
\hline & Berat & $\begin{array}{c}0,0 \\
(0,0 \%)\end{array}$ & $\begin{array}{c}10 \\
(9,9 \%)\end{array}$ & $\begin{array}{c}10 \\
(9,9 \%)\end{array}$ \\
\hline Obstruksi & Ringan & $\begin{array}{c}3 \\
(3,0 \%)\end{array}$ & $\begin{array}{c}9 \\
(8,9 \%)\end{array}$ & $\begin{array}{c}12 \\
(11,9 \%)\end{array}$ \\
\hline \multicolumn{2}{|c|}{ Combined defect } & $\begin{array}{c}0,0 \\
(0,0 \%)\end{array}$ & $\begin{array}{c}8 \\
(7,9 \%) \\
\end{array}$ & $\begin{array}{c}8 \\
(7,9 \%) \\
\end{array}$ \\
\hline \multicolumn{2}{|c|}{ Total $(\%)$} & $\begin{array}{c}26 \\
(25,7 \%) \\
\end{array}$ & $\begin{array}{c}75 \\
(74,3 \%) \\
\end{array}$ & $\begin{array}{c}101 \\
(100 \%) \\
\end{array}$ \\
\hline
\end{tabular}

\subsection{Karakteristik Lingkungan Kerja Bengkel Sepeda Motor di Kota Denpasar}

Lingkungan kerja bengkel dalam penelitian ini dinilai dengan melakukan pengukuran pada parameter seperti CO pada udara ambien, debu, pencahayaan, kebisingan, iklim kerja yang mencakup ISBB dan kelembaban udara. Hasil pengukuran lingkungan kerja disajikan selengkapnya pada Tabel 4. Berdasarkan tabel 4, diketahui bahwa konsentrasi gas $\mathrm{CO}$ pada udara ambien bengkel berada dalam rentang baku mutu yang diperkenankan yaitu $<30.000 \mu \mathrm{g} / \mathrm{m}^{-3}$. Nilai hasil pengukuran CO ambien bengkel adalah 313,33 $606,67 \mu \mathrm{g} / \mathrm{m}^{-3}$. Berkebalikan dengan nilai CO yang $100 \%$ masih berada dalam level normal, maka nilai pengukuran kadar debu total/TSP (total suspended particle) dari 20 sampel debu ruang kerja yang diuji dengan menggunakan alat Nephelometer diketahui bahwa 90\% ruang kerja bengkel memiliki kadar debu total di atas nilai baku mutu berdasarkan Peraturan Gubernur Bali No. 8 Tahun 2007 (Gubernur Bali, 2007). Ditemukan bahwa saat puncak servis kendaraan ditemukan rentang nilai debu total adalah $208,00-494,67{\mu \mathrm{gm}^{-3}}^{-}$. 
Servis kendaraan bermotor merupakan suatu pekerjaan rutin yang bersifat kasar dan terus menerus yang dilakukan dengan menggunakan mesin dan melakukan perakitan mesin. Menurut Kemenkes RI No. 1405/Menkes/SK/XI Tahun 2002, disebutkan pencahayaan yang diperlukan untuk jenis pekerjaan seperti di ruang servis kendaraan sepeda motor adalah sebesar 200-300 lux (Kementerian Kesehatan Republik Indonesia, 2002). Pencahayaan di ruang bengkel sepeda motor di Kota Denpasar diketahui pada rentang 51,6 - 515,2 lux. Sebanyak 35\% dari jumlah bengkel yang diukur diketahui memiliki intensitas pencahayaan yang masih kurang dari NAB yang dipersyaratkan yaitu 4 bengkel termasuk kelas $\mathrm{B}$ dan 3 bengkel di kelas C.

Kebisingan ruang kerja di bengkel kelas A telah memenuhi baku mutu yaitu $<85 \mathrm{dBA}$, tetapi 2 bengkel di kelas B dan 3 bengkel di kelas $\mathrm{C}$ masih di atas baku (Peraturan Menteri Tenaga Kerja dan
Transmigrasi Republik Indonesia Nomor Per.13/ Men/X/2011). Untuk parameter iklim kerja yang tercermin dari nilai ISBB, semua bengkel yang diteliti di Kota Denpasar telah memenuhi baku mutu (Peraturan Menteri Tenaga Kerja dan Transmigrasi Republik Indonesia Nomor Per.13/Men/X/2011). Selengkapnya tentang hasil pengukuran lingkungan kerja dapat dilihat pada Tabel 4.

\subsection{Pelaksanaan Standar Operasional Prosedur di Bengkel Sepeda Motor di Kota Denpasar}

Parameter pelaksanaan prosedur standar kerja di bengkel sepeda motor tidak semuanya dapat dipenuhi dan dilaksanakan oleh pihak manajemen bengkel. Parameter tersebut mencakup penggunaan APD (Alat Pelindung Diri), keberadaan toilet pria dan wanita sesuai dengan jumlah pekerja, kotak P3K (Pertolongan Pertama Pada Kecelakaan) dan isiannya belum sesuai dengan rekomendasi, ceceran

Tabel 4. Rekapitulasi Nilai Pengukuran Variabel Lingkungan Kerja Bengkel di Kota Denpasar Tahun 2015

\begin{tabular}{|c|c|c|c|c|c|c|c|c|c|}
\hline \multirow{2}{*}{ NO } & \multirow{2}{*}{ KELAS } & \multirow{2}{*}{ KODE } & \multicolumn{7}{|c|}{ PENGUJIAN LINGKUNGAN KERJA } \\
\hline & & & $\begin{array}{c}(\mathrm{co} \\
\left(\mu \mathrm{gm}^{-3}\right)\end{array}$ & 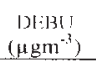 & $\begin{array}{l}\text { PENCAHAYAAX: } \\
\text { (IUX) }\end{array}$ & $\begin{array}{l}\text { KEBISINGAN } \\
(\text { dBA })\end{array}$ & $\begin{array}{l}\operatorname{ISBB} \\
\left({ }^{\circ} \mathrm{C}\right) \\
\end{array}$ & $\begin{array}{r}\mathrm{RH} \\
(\%) \\
\end{array}$ & $\begin{array}{l}\text { WS } \\
\text { ms }\end{array}$ \\
\hline 1 & A & $\mathrm{Al}$ & 586,67 & 470,50 & 408,40 & 76,90 & 25,85 & 84,00 & 0,4 \\
\hline 2 & A & $\mathrm{A} 2$ & 341,33 & 208,00 & 363,20 & 67.56 & 27,30 & 67,00 & 0,5 \\
\hline 3 & A & A3 & 389,33 & 281,14 & 230,60 & 69,28 & 27,70 & 77,00 & 0,3 \\
\hline 4 & $\mathrm{~B}$ & $\mathrm{~B} 1$ & 536,00 & 326,67 & 353,20 & 77,34 & 27,40 & 74,50 & 0,3 \\
\hline 5 & B & B2 & 352.00 & 214,75 & 326,40 & 66,26 & 26,00 & 73,50 & 0,5 \\
\hline 6 & B & B3 & 394,67 & 263,00 & 167,20 & 76,68 & 26,30 & 74,00 & 0,3 \\
\hline 7 & B & B4 & 532,33 & 352,45 & 51,60 & 73,86 & 27.50 & 86,67 & 0,4 \\
\hline 8 & B & $\mathrm{B} 5$ & 313,33 & 321.67 & 51,67 & 76.70 & 28,60 & 77.50 & 0,4 \\
\hline 9 & B & B6 & 580,00 & 493.67 & 355,60 & 83.94 & 27,45 & 75,00 & 0.5 \\
\hline 10 & B & $\mathrm{B} 7$ & 606,67 & 354,50 & 454,20 & 81,16 & 27.97 & 63,67 & 0.5 \\
\hline 11 & B & B8 & 598,20 & 361.00 & 291.60 & 76,72 & 28.00 & 74,00 & 0,3 \\
\hline 12 & B & B9 & 412,77 & 239,33 & 159,40 & 70,44 & 27,55 & 75,50 & 0,3 \\
\hline 13 & $\mathrm{C}$ & $\mathrm{Cl}$ & 462,67 & 320,50 & 137,60 & 81,88 & 25,70 & 78,00 & 0,3 \\
\hline 14 & $\mathrm{C}$ & $\mathrm{C}_{2}$ & 286,70 & 360,12 & 515,20 & 75,61 & 28,01 & 78,50 & 0,6 \\
\hline 15 & $\mathrm{C}$ & $\mathrm{C} 3$ & 501,42 & 461,14 & 120,15 & 80,12 & 27,25 & 79,00 & 0,5 \\
\hline 16 & $\mathrm{C}$ & $\mathrm{C} 4$ & 361.20 & 312,01 & 230,00 & 73,56 & 26,15 & 85,25 & 0,5 \\
\hline 17 & $C$ & $C_{5}$ & 471,55 & 360,15 & 327,12 & 72,46 & 26,00 & 80,45 & 0,4 \\
\hline 18 & $\mathrm{C}$ & $\mathrm{C} 6$ & 371,42 & 281,17 & 231,19 & 71,80 & 27,50 & 78,00 & 0,5 \\
\hline 19 & $\mathrm{C}$ & $\mathrm{C} 7$ & 381.90 & 330,10 & 409,10 & 76,15 & 28,20 & 78,00 & 0,6 \\
\hline 20 & $C$ & $\mathrm{C} 8$ & 530,22 & 370.18 & 127,70 & 81,15 & 28,61 & 76,50 & 0,3 \\
\hline
\end{tabular}

Keterangan Tabel 4. Nilai Baku Mutu Pengujian Lingkungan

\begin{tabular}{|c|c|c|c|}
\hline No & Parameter & NAB & Keterangan \\
\hline 1 & $\mathrm{CO}$ & $30.000 \mu^{-3}$ & Pengukuran 1 jam \\
\hline 2 & Debu total & $230 \mu \mathrm{gm}^{-3}$ & Pengukuran 24 jam \\
\hline 3 & Pencahayaan & $200-300 \operatorname{lux}$ & $\begin{array}{l}200 \text { lux : pekerjaan dengan mesin dan perakitan kasar } \\
300 \text { lux : R.Administrasi, R. Kontrol, pekerjaan mesin dan } \\
\text { perakitan/penyusun }\end{array}$ \\
\hline 4 & Kebisingan & $85 \mathrm{dBA}$ & Untuk pemaparan harian 8 jam \\
\hline 5 & ISBB & $28-31^{\circ} \mathrm{C}$ & $\begin{array}{l}\text { Beban kerja ringan - sedang dengan pengaturan waktu kerja } \\
\text { setiap jam } 75-100 \%\end{array}$ \\
\hline 6 & RH (Kelembaban) & $65 \%-95 \%$ & \\
\hline 7 & WS (wind speed) & $0,15-0,25 \mathrm{~ms}^{-1}$ & \\
\hline
\end{tabular}


oli di ruang kerja serta diklat pekerja mekanik di bidang K3 (Keselamatan dan Kesehatan Kerja) belum sepenuhnya dilaksanakan pada pekerja mekanik. Tetapi indikator seperti perijinan, dokumen SOP, ventilasi ruang kerja, penampung limbah B3 (Bahan Berbahaya dan Beracun), pengaturan jam kerja serta tempat sampah telah terpenuhi dengan baik pada semua bengkel.

\subsection{Keluhan Muskuloskeletal Pekerja Mekanik Sepeda Motor di Kota Denpasar}

Keluhan muskuloskeletal didata menggunakan kuesioner Nordic Body Map. Kuesioner Nordic Body Map berisikan 28 (dua puluh delapan) pertanyaan menyangkut keluhan yang dirasakan selama bekerja sesuai dengan masing-masing regio tubuh. Pada kuesioner tersebut para mekanik diminta untuk mengisi jenis tingkatan keluhan yang dirasakan mulai dari tidak ada keluhan (A), kesemutan/sedikit sakit (B), sakit (C) dan sangat sakit (D) sesuai dengan nomor yang ditunjukkan pada gambar Tabel 5. Dari kuesioner diperoleh bahwa pekerja mekanik di bengkel kelas A banyak mengeluh sangat nyeri pada lutut, pergelangan tangan dan bahu. Pada bengkel kelas B keluhan sangat nyeri dominan pada leher atas, pergelangan tangan, lutut dan kaki. Demikian juga karyawan bengkel kelas $\mathrm{C}$ banyak mengeluhkan sangat nyeri pada tangan, paha, leher, pinggang dan punggung. Selengkapnya dapat dilihat pada Tabel 5 .

\subsection{Keluhan Kelelahan Pekerja Mekanik Bengkel Sepeda Motor di Kota Denpasar Keluhan kelelahan pekerja mekanik bengkel diukur dengan kuesioner SSRT (Subjective Self Rating Test). Kelelahan merupakan kondisi yang}

Tabel 5. Rekapitulasi Tingkat Keluhan Muskuloskeletal Mekanik Sepeda Motor di Kota Denpasar Tahun 2015.

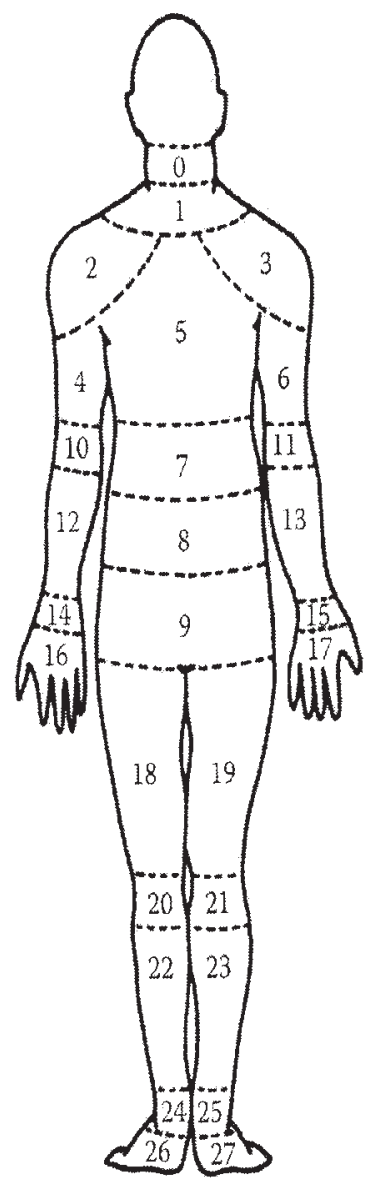

\begin{tabular}{|c|c|c|c|c|c|c|c|c|c|c|c|c|}
\hline \multirow{4}{*}{ 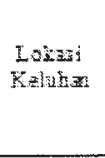 } & \multicolumn{12}{|c|}{ TINGKAT KEL CHAN BERDASARKAN NORDIC BODY MAP OUESTONALIRE } \\
\hline & \multicolumn{3}{|c|}{$\mathbf{x}$} & \multicolumn{3}{|c|}{$\mathbf{B}$} & \multicolumn{3}{|c|}{ c } & \multicolumn{3}{|c|}{$\mathbf{D}$} \\
\hline & ! & II & III & I & II & III & I & II & III & I & U & In \\
\hline & \multicolumn{3}{|c|}{ 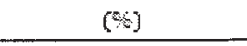 } & \multicolumn{3}{|c|}{$(\%)$} & \multicolumn{3}{|c|}{$06]$} & \multicolumn{3}{|c|}{$[\%]$} \\
\hline 6 & 71,43 & 48,60 & 40,07 & $0, \infty$ & 23,00 & 30,07 & 28,57 & 12,00 & 66 & $\$, \infty$ & $12, \infty$ & 10,0 \\
\hline : & 71,43 & $\infty, \infty$ & 73,33 & 0,00 & $18, \infty 0$ & 13,33 & 28,57 & $16, \infty$ & 13,33 & 9,80 & $0, \infty$ & $0, \infty$ \\
\hline 2 & 19,05 & $4, \infty$ & 30,67 & 47,62 & 38,00 & $56,0^{7}$ & 19,05 & $12, \infty$ & 6 & 14,29 & $4, \infty 0$ & $0, \infty$ \\
\hline 3 & 32,38 & 56,00 & $\$ 0, \infty$ & 23,81 & $22, \infty$ & 1067 & 14,20 & 22,00 & 13,35 & 9,52 & 0,00 & 10,00 \\
\hline 4 & 5667 & 36,00 & 63,35 & 23,81 & 52,00 & 30,00 & 4,76 & $12, \infty$ & 6 & 436 & $0, \infty$ & 0,00 \\
\hline 5 & 28,57 & 5,00 & 26.67 & 28,57 & $14, \infty$ & 50,00 & 38,10 & 30,00 & 15,33 & 4,78 & 0,00 & 10,0 \\
\hline 6 & 66,67 & $58, \infty$ & 46.67 & 23,81 & 30,00 & 33,33 & 4,76 & 12,00 & $20, \infty$ & 4,78 & $0_{3} \infty$ & 0,00 \\
\hline 7 & 52,38 & $6, \infty$ & $366 ?$ & 33,33 & $18, \infty 0$ & $30, \infty$ & 14,29 & 22,00 & $33_{3} 3$ & 0,00 & $0, \infty$ & 10,00 \\
\hline 8 & 76,19 & 0,00 & 63,33 & 14,20 & 28,00 & 30,00 & $0, \infty$ & $12, \infty$ & 0,0 & 0,32 & 0,00 & 0,00 \\
\hline$\theta$ & 7,19 & $40, \infty$ & $\infty, \infty$ & 14,29 & 20,00 & 26,67 & $0, \infty$ & $40, \infty 0$ & 13,33 & 9,52 & 0,00 & 0,80 \\
\hline 10 & $01, \infty$ & 50,00 & $48,6 ?$ & 10,05 & $32, \infty$ & 30,6 & 9,52 & $18, \infty$ & 6,5 & 9,52 & $0, \infty$ & 10,00 \\
\hline 11 & 71,43 & $38, \infty$ & 36,67 & 23,81 & $18, \infty$ & $30, \infty$ & 4,70 & $44, \infty$ & 13,33 & $0, \infty$ & $6, \infty$ & 0,0 \\
\hline 12 & 57,14 & 02,0 & 30,00 & 23,57 & $8, \infty$ & 26 & $14: 29$ & $20, \infty$ & 39,33 & $\infty \infty$ & 4,0 & 10,00 \\
\hline 13 & 61,00 & 54,00 & 53,33 & 19,05 & $20, \%$ & 33,33 & 0,52 & $26, \infty$ & 13.33 & 8,52 & $0, \infty$ & 0.00 \\
\hline 14 & 52,38 & 68,0 & 30,00 & 10,05 & 12,00 & $18 \times$ & 9,5 & 12,00 & 23,33 & 19,05 & $\$, \infty$ & $10, \infty$ \\
\hline 15 & 52,38 & $85, \infty$ & 40,00 & 23,51 & $16, \infty$ & 33,33 & 14,20 & $16, \infty$ & 26.67 & 852 & 0,00 & 0,00 \\
\hline 16 & 7819 & $-6, \infty$ & 53,33 & 18,05 & $12, \infty$ & 160 & 4.76 & $12, \infty$ & 60 & $0, \infty$ & 0,00 & 23,33 \\
\hline 17 & 71,43 & $68, \infty$ & 53,33 & 28,57 & $16, \infty$ & 33,33 & 0,00 & $16, \infty$ & 13,33 & 0,00 & $0, \infty$ & 0,0 \\
\hline 18 & $61, \infty$ & $7,2,00$ & 7,33 & 19,05 & $16, \infty$ & $10, \infty$ & 14,25 & 12,00 & 66 & 4,76 & $0, \infty$ & 10,0 \\
\hline 19 & 01,90 & $50, \infty$ & $40, \infty$ & 19,05 & $24, \infty$ & 33,33 & 9,52 & $16, \infty$ & 13,33 & 8,52 & $4, \infty$ & 13,33 \\
\hline 20 & 45,62 & 54,60 & 80,00 & 10,05 & $34, \infty$ & 13,33 & 9,52 & 12,0 & 6,6 & 23,81 & $\infty, \infty$ & $0, \infty 0$ \\
\hline 21 & 4,62 & $44, \infty$ & $36,6 ?$ & 10,05 & $36, \infty$ & 4000 & 8,52 & $16, \infty$ & $1,3,33$ & 25,81 & $4, \infty$ & 10,0 \\
\hline 22 & 57,14 & $54, \infty$ & 70,0 & $14: 29$ & $34, \infty$ & 23,33 & 18,05 & 12,00 & 6,67 & 0,52 & $0, \infty$ & 0,0 \\
\hline 23 & 5,14 & $48, \infty$ & 23,33 & 14,20 & 36,06 & 63,33 & 19,05 & $18, \infty 0$ & 13,33 & 052 & 0,60 & 0,00 \\
\hline 24 & 71.43 & 54,00 & $6, \infty$ & $14: 29$ & 34,0 & 13.33 & 0,52 & 12,00 & 26,67 & 4.8 & 0,0 & $0, \infty$ \\
\hline 25 & 61,00 & $54, \infty$ & 40,00 & 23,81 & 30,00 & 36,67 & 4,70 & 10,00 & $1.3,33$ & 9,52 & $0, \infty$ & 10,6 \\
\hline 20 & 7,10 & $4, \infty$ & 50,0 & 10,05 & 40,00 & 13,33 & 4,70 & $12, \infty$ & 0,07 & $\$, \infty$ & 4,00 & $0, \infty$ \\
\hline 27 & 76,19 & 70,80 & 60,00 & 14,28 & 12,00 & 26,6 & 0,52 & 14,00 & $13 \times 33$ & 0,80 & $4, \infty$ & $0, \infty$ \\
\hline
\end{tabular}

Keterangan Tabel 5.

A

Tidak ada keluhan I

Bengkel kelas A

Lokasi Keluhan :

\section{B}

Kesemutan/sedikit sakit

Bengkel kelas B

Nomor lokasi keluhan muskuloskeletal karyawan sesuai dengan Gambar

D

Sakit
III

Bengkel kelas C menunjukkan tempat keluhan 
ditandai dengan perasaan lelah dan menurunnya kesiagaan serta berpengaruh terhadap produktivitas kerja (Oesman dan Simanjuntak, 2011). Kelelahan kerja dalam suatu industri berkaitan pada 3 (tiga) gejala yang saling berhubungan yaitu perasaan lelah, penurunan fisiologis dalam tubuh dan menurunnya kapasitas kerja (Tarwaka et al., 2004). Dari kuesioner diperoleh persentase skor tertinggi pelemahan kegiatan (I), pelemahan motivasi (II) dan kelelahan fisik (III) ada pada bengkel kelas B, dengan nilai berturut - turut $62 \%$ pada pelemahan kegiatan, $39 \%$ pada pelemahan motivasi dan $47 \%$ pada kelelahan fisik. Selengkapnya dapat dilihat pada Tabel 6.

Tabel 6. Rekapitulasi Nilai Kelelahan Mekanik Sepeda Motor Berdasarkan Kuesioner SSRT dari IFRC di Kota Denpasar Tahun 2015.

\begin{tabular}{ccccccc}
\hline & \multicolumn{4}{c}{ Skor Tingkat Kelelahan Pekerja Mekanik } \\
\cline { 2 - 7 } Bengkel & \multicolumn{2}{c}{ I } & \multicolumn{2}{c}{ II } & \multicolumn{3}{c}{ III } \\
\cline { 2 - 7 } & $\mathrm{N}$ & $\%$ & $\mathrm{~N}$ & $\%$ & $\mathrm{~N}$ & $\%$ \\
\hline $\mathrm{A}$ & $111[210]$ & 53 & $61[210]$ & 29 & $63[210]$ & 30 \\
$\mathrm{~B}$ & $312[500]$ & 62 & $193[500]$ & 39 & $233[500]$ & 47 \\
$\mathrm{C}$ & $134[300]$ & 45 & $42[500]$ & 14 & $92[500]$ & 31 \\
\hline
\end{tabular}

Keterangan

I Pertanyaan kuesioner nomor $1-10$

II Pertanyaan kuesioner nomor 11-20

III Pertanyaan kuesioner nomor 21-30

\subsection{Analisis Pengaruh Parameter Penelitian}

Dalam penelitian ini, variabel kualitas lingkungan kerja (CO, debu total, pencahayaan, kebisingan, dan ISBB) dan penerapan SOP merupakan variabel bebas serta variabel keluhan kesehatan dan kelelahan serta fungsi paru pekerja mekanik yang merupakan variabel tergantung kemudian dianalisis untuk mengetahui pengaruh dari variabel bebas terhadap variabel tergantung. Analisis dilakukan dengan bantuan software SPSS 17.0 (IBM, 2013). Dari analisis statistik regresi sederhana yang dilakukan, diperoleh hasil seperti pada Tabel 7. Ditemukan bahwa semua variabel pada kualitas lingkungan dan pelaksanaan standar operasional prosedur bengkel memiliki pengaruh terhadap kesehatan pekerja mekanik yang meliputi keluhan muskuluskeletal dan keluhan kelelahan pada pekerja mekanik bengkel sepeda motor di Kota Denpasar $(\mathrm{p}<0,15)$.

Variabel CO ambien $(\mathrm{R}>0,697)$ dan debu total lingkungan kerja $(\mathrm{R}=0,612)$ pada Tabel 8 menunjukkan pengaruh yang signifikan $(R>0,50)$ terhadap keluhan pada fungsi paru pekerja mekanik di Kota Denpasar. Nilai R menjelaskan bahwa variabel CO memiliki hubungan sebesar 69,7\%, dan debu total memiliki hubungan sebesar $61,2 \%$ terhadap kejadian gangguan fungsi paru pada pekerja mekanik di bengkel sepeda motor. Berdasarkan nilai $\mathrm{R}^{2}$ di Tabel 8, dapat ditentukan bahwa CO ambien memberikan variasi sebesar $48,5 \%$ terhadap terjadinya gangguan fungsi paru karyawan, sedangkan debu total memberikan variasi sebesar

Tabel 7. Nilai Statistik Analisis Regresi Sederhana Kualitas Lingkungan dan Penerapan Standar Operasional Prosedur Bengkel Terhadap Keluhan Muskuloskeletal dan Kelelahan Pekerja Mekanik Sepeda Motor di Kota Denpasar Tahun 2015

\begin{tabular}{|c|c|c|c|c|c|c|c|c|c|c|}
\hline \multirow[b]{2}{*}{ No } & \multirow[b]{2}{*}{$\begin{array}{l}\text { Variabel bebas } \\
\qquad(\mathrm{X})\end{array}$} & \multirow[b]{2}{*}{ Kode } & \multicolumn{4}{|c|}{ Keluhan Muskuloskeletal } & \multicolumn{4}{|c|}{ Keluhan Kelelahan } \\
\hline & & & $\mathrm{R}$ & $\mathrm{R}^{2}$ & $\begin{array}{c}\text { Sig } \\
(\mathrm{p}<0,15)\end{array}$ & Persamaan & $\mathrm{R}$ & $\mathrm{R}^{2}$ & $\begin{array}{c}\text { Sig } \\
(p<0,15)\end{array}$ & Persamaan \\
\hline 1 & CO & $\mathrm{X} 1$ & 0,255 & 0,065 & 0,001 & $\mathrm{Y}=77,329+0,037 \mathrm{X} 1$ & 0,521 & 0,271 & 0,000 & $\mathrm{Y}=3.136+0,021 \mathrm{X} 1$ \\
\hline 2 & DEBU & $x_{2}$ & 0,157 & 0,025 & 0,117 & $Y=85,560+0,026 \times 2$ & 0,408 & 0,166 & 0,000 & $Y=6,513+0,018 \times 2$ \\
\hline 3 & PENCAHAYAAN & $\mathrm{X} 3$ & 0,211 & 0,045 & 0.034 & $Y=99.637-0,023 \times 3$ & 0,148 & 0,022 & 0,141 & $Y=13,522-0,004 \times 3$ \\
\hline 4 & KABISINGAN & $\mathrm{X} 4$ & 0.288 & 0.083 & 0,004 & $Y=39,349+0,732 X 4$ & 0.258 & 0,066 & 0,009 & $Y=-1,045+0,181 X 4$ \\
\hline 5 & ISBB & $\mathrm{x} 5$ & 0,249 & 0,062 & 0,012 & $Y=-10.094+3.819 \times 5$ & 0.178 & 0.032 & 0,075 & $Y=-8.006+0.750 \times 5$ \\
\hline 6 & PELAKSANAAN SOP & $\mathrm{X} 6$ & 0.245 & 0,060 & 0,014 & $Y=70,619+0,850 \times 6$ & 0,141 & 0,020 & 0,148 & $Y=8,705+0,135 \times 6$ \\
\hline
\end{tabular}

Tabel 8. Nilai Statistik Analisis Regresi Sederhana Kualitas Lingkungan dan Penerapan Standar Operasional Prosedur Bengkel Terhadap Fungsi Paru Pekerja Mekanik Sepeda Motor di Kota Denpasar Tahun 2015

\begin{tabular}{llccccc} 
& & & \multicolumn{3}{c}{ Analisis Regresi Sederhana } \\
\cline { 4 - 7 } No & Variabel bebas $(\mathrm{X})$ & Kode & $\mathrm{R}$ & $\mathrm{R}^{2}$ & $\begin{array}{c}\text { Sig } \\
(\mathrm{p}<0,05)\end{array}$ & Persamaan \\
\hline 1 & CO & $\mathrm{X} 1$ & 0,697 & 0,485 & 0,000 & $\mathrm{Y}=14,385+0,131 \mathrm{X} 1$ \\
2 & DEBU & $\mathrm{X} 2$ & 0,612 & 0,374 & 0,000 & $\mathrm{Y}=31,325+0,132 \times 2$ \\
3 & PELAKSANAAN & $\mathrm{X} 3$ & 0,153 & 0,024 & 0,126 & $\mathrm{Y}=54,257+0,699 \times 6$ \\
& SOP & & & & & \\
\hline
\end{tabular}


37,4\% terhadap kejadian gangguan fungsi paru pada pekerja mekanik. Variabel ketiga yaitu pelaksanaan standar operasional prosedur bengkel memiliki hubungan dengan terjadinya gangguan fungsi paru sebesar $15,3 \%(\operatorname{Sig}=0,126 ; p<0,15)$, dengan variasi pengaruh sebesar $2,4 \%\left(R^{2}=0,024\right)$.

\section{SIMPULAN DAN SARAN}

\subsection{Simpulan}

Berdasarkan atas hasil penelitian dan pengukuran terhadap kualitas lingkungan kerja, penerapan prosedur operasi standar bengkel servis kendaraan, dan kesehatan mekanik di Kota Denpasar dapat disimpulkan sebagai berikut :

1. Kualitas lingkungan kerja bengkel servis sepeda motor di Kota Denpasar yang diukur melalui parameter $\mathrm{CO}$, pencahayaan, kebisingan dan iklim kerja masih berada dalam rentang baku mutu. Hanya 1 (satu) parameter yang tidak memenuhi baku mutu yakni parameter debu total di ruang kerja bengkel.

2. Pelaksanaan prosedur operasi standar kerja di stasiun servis kendaraan di bengkel sepeda motor di Kota Denpasar yang mencakup dokumen SOP, ijin bengkel, dokumen pengelolaan limbah B3 serta papan peringatan terkait K3 telah terpenuhi dan dilaksanakan dengan baik. Tetapi pada parameter sanitasi lingkungan, kelengkapan P3K, kesiapan dan kelengkapan alat pelindung diri (APD) bagi pekerja mekanik, ruang istirahat serta ceceran oli yang masih banyak ditemukan diketahui belum terlaksana dengan baik.

3. Para Pekerja mekanik di bengkel sepeda motor di Denpasar mayoritas memiliki keluhan pada fungsi paru serta pada sistem muskuloskeletal dan kelelahan dalam tingkat dan macam yang berbeda.

4. Hasil analisis statistik mendapatkan bahwa semua variabel dalam lingkungan kerja dan pelaksanaan prosedur operasi standar kerja berhubungan dengan kesehatan para Pekerja mekanik bengkel sepeda motor. Namun hanya komponen $\mathrm{CO}$ ambien $(\mathrm{R}=0,697)$ serta debu $(\mathrm{R}$ $=0,612)$ yang berpengaruh secara signifikan $(\mathrm{R}$ $>0,50)$ terhadap kesehatan para Pekerja mekanik bengkel sepeda motor di Kota Denpasar.

\subsection{Saran}

1. Disarankan kepada Pemerintah Kota melalui dinas atau SKPD terkait dapat melakukan penerapan aturan yang berlaku secara utuh (holistik) terkait dengan ijin, pembinaan dan pengawasan di bidang usaha perbengkelan. Selain itu petugas atau tim pelaksana tugas yang menaungi di lingkup usaha bengkel di Kota
Denpasar dapat melaksanakan tugas dan fungsi supervisi secara lebih intensif.

2. Para pemilik usaha bengkel bengkel sepeda motor di Kota Denpasar agar bersungguhsungguh mengupayakan terciptanya lingkungan kerja yang sehat bagi seluruh karyawan bengkel dengan memperhatikan seluruh ketentuan dan peraturan yang ada. Di samping itu juga agar para pimpinan bengkel senantiasa meningkatkan edukasi dan kesadaran para Pekerja mekanik supaya senantiasa taat dan disiplin dalam melakukan semua prosedur kerja di ruang servis dalam upaya penanggulangan penyakit akibat kerja (PAK) akibat paparan faktor risiko di tempat kerja dan kecelakaan kerja karena kesalahan prosedur.

\section{DAFTAR PUSTAKA}

Budiono, I. 2007. Faktor Risiko Gangguan Fungsi Paru Pada Pekerja Pengecatan Mobil (Studi pada Bengkel Pengecatan Mobil di Kota Semarang). (Tesis). Program studi Magister Epidemiologi Universitas Diponegoro. Semarang.

Daryanto. 2010. Keselamatan Kerja dan Peralatan Bengkel dan Perawatan Mesin. CV.Alfabeta. Bandung.

Dinas Perhubungan Propinsi Bali. 2011. Jumlah Kendaraan Bermotor Propinsi Bali tahun 1998 s/d 2010. Denpasar.

Gubernur Bali. 2007. Peraturan Gubernur Bali No.8 Tahun 2007 Tentang Baku Mutu Lingkungan Hidup dan Kriteria Baku Kerusakan Lingkungan Hidup. Denpasar.

Harrianto, R. 2010. Buku Ajar Kesehatan Kerja. Penerbit Buku Kedokteran EGC. Jakarta.

Hiperkes Bali. 2010. SOP Kerja Metode Laboratorium. 2010. Metode Pengukuran Kualitas Udara. Dinas Tenaga Kerja dan Transmigrasi Propinsi Bali.UPT. Balai Hiperkes dan KK. Denpasar.

IBM. 2013. IBM SPSS Statistics ver 17.0. Available at http://www-01.ibm.com/software/analytics/ spss/.

Kementerian Kesehatan Republik Indonesia. 2002. Keputusan Menteri Kesehatan Republik Indonesia Nomor 1405/Menkes/SK/XI/2002 Tentang Persyaratan Kesehatan Lingkungan Kerja Perkantoran Dan Industri.

Kementerian Tenaga Kerja dan Transmigrasi Republik Indonesia. 2011. Peraturan Menteri Tenaga Kerja dan Transmigrasi Republik Indonesia Nomor Per.13/Men/X/2011 tentang 
Nilai Ambang Batas Faktor Fisika dan Kimia di Tempat Kerja

Korlantas Polri. 2012. Sembilan Puluh Empat Juta Mobil dan Sepeda Motor Berseliweran di Jalanan Indonesia, Available at : http://otomotif. kompas.com/read/2013/02/26/6819/94.2 .juta. Mobil.dan. Sepeda. Motor. Berseliweran. di. Jalanan. Indonesia, (Akses: 20 Desember 2013).

Kuorinka, I., B. Jonsson., A. Kilbom., H. Vinterberg., F.B Sorenson., G. Andersson., and K. Jorgenson. 1987. Standardised Nordic Questionnaires for The Analysis of Musculoskeletal Symptoms. In : Applied Ergonomics 1987. 18.3. 233-237. Available at: www.uresp.ulaval.ca/backpaindefs/ en/PDF/KuorinkaPaper. pdf. (Akses : 12 Desember 2014).

Mahardika, P. M. 2012. Pengaruh Paparan Emisi Kendaraan Bermotor Terhadap Frekuensi Pembentukan Mikronukleus Di Mukosa Rongga Mulut Pada Mekanik Bengkel Motor. Available at : http://ejournal-s1.undip.ac.id/index.php/ medico/article/viewFile/1810/1819. (Akses : 3 Januari 2014).

Menteri Tenaga Kerja dan Transmigrasi RI. 2011. Peraturan Menteri Tenaga Kerja dan Transmigrasi No. Per. 13/Men/X/2011 tentang Nilai Ambang Batas Faktor Fisika dan Faktor Kimia di Tempat Kerja. Jakarta.
Oesman, T.I dan R.A. Simanjuntak. 2011. Hubungan Faktor Internal dan Eksternal Terhadap Kelelahan Kerja Melalui Subjective Self Rating Test. Proceeding $11^{\text {th }}$ National Conference of Indonesian Ergonomics Society 2011. Available at: http://repository.akprind.ac.id/repo/author/ 321. (Akses : 3 Juli 2015).

Saito, K. 1999. Measurement of Fatigue in Industries. Industrial Health Journal 1999. 37. 134-142. Available at: https://www.jstage. jst.go. jp/article/ indhealth1963/37/2/37_2_134/_pdf. (Akses : 12 Desember 2014).

Sayoga, M.A. 2001. Pengaruh Masa Pakai Dan Tingkat Transmisi Terhadap Kadar Emisi Gas Buang Sepeda Motor Honda Astrea Grand. Available at: http://ejournal.ftunram.ac.id/ FullPaper/sayoga.pdf. (Akses : 3 Januari 2014).

Suma'mur, P.K. 1980. Higiene Perusahaan dan Kesehatan Kerja. Cetakan Ketiga. Gunung Agung. Jakarta.

Tugaswati., A.T. 2012. Emisi Gas Buang Kendaraan Bermotor dan Dampaknya Terhadap Kesehatan. Available at: http://www.kpbb.org/makalah_ind/ Emisi\%20Gas\%20Buang\%20Bermotor\%20\% 26\%20Dampaknya\%20Terhadap\%20 Kesehatan. pdf. (Akses : 3 Januari 2014). 